\title{
The Role of Development of Farmers' Cooperatives
}

\author{
Ma.Sc.Mehdi PLLASHNIKU, PhD.Cand.
}

\begin{abstract}
This abstract is a summary of scientific review of the present paper. As new circumstances have been created after the last war in Kosovo, it is of high importance and urgency to create and build a new mentality for the development of Farmers' Cooperatives (FC). The Farmers' Cooperatives have played an important role in the past and they continue to act so, both nationwide and globally. The practice for organization of farmers in their cooperatives of the International Cooperative Alliance (ICA) has enabled the creation of a membership of more than 800 million farmers who employ more than 100 million people. Their participation in the supply of the market reaches 33\% of the total world production. Farmers' cooperatives are organizations in which farmers retain private ownership of the land. The profit from the cooperatives is of a considerable variety and the practice of such organization has shown its positive effects through strengthening of the farmers and raising their profit, facing the market and creation of a positive business. This is based on the opinion of a number if scientists of this field. They divide the farmer' profit in direct and indirect type. As far as Kosovo is concerned, the development of farmers' cooperatives is delayed although the necessary legislation (the Law on Cooperatives) is applied. On that basis the conditions for strengthening the role of the farmers is of high urgency. This paper consists of two parts: In the first part the respective legislation of Kosovo in relation to the role of farmers' cooperatives is going to be presented. The second part presents the conditions for establishment, rights, duties and statics of the farmers' cooperatives. In this paper is analysed the role of development of farmers' cooperatives in general. At the end, a summary of the above will be presented in analytical form, including recommendations and conclusions.
\end{abstract}

Keywords: Cooperative, Farmers, Law, Kosovo, Federation, income, etc.

\section{Introduction}

Historically, Farmers' Cooperatives existed for a long time, including the time of former SFRY. One of the organizational forms for performing activities according to applicable laws of then was through Farmers' Cooperatives. However after the last war in 1999 all Socially Owned Enterprises, Public Enterprises and Farmers' Cooperatives fall under UNMIK administration. Until 2003, respectively entry into force of the Law No.2003/9 on Farmers' Cooperatives, no Farmers' Cooperatives were subject to any registration process. Based on the research work of applications filed with the Agency for Registration of Businesses, up to date, a total of 83 farmers' cooperatives have been registered.

\section{Purpose of the paper}

The purpose of this paper is the identification of the factors effecting the development of the farmers' cooperatives. This would help in undertaking preventive measures for:

- $\quad$ Creation of agricultural zones

- Facilitating granting of low interest rate loans,

- Contribution of farmers' cooperatives in the creation of jobs, income, application of new technologies, intensification of cooperation between businesses, intensification of the competition.

- $\quad$ Provision of supply of markets and entering markets for acquisition of inputs and sale of products represent the two most important advantages offered by farmers' cooperatives,

- Supporting of family farms,

- $\quad$ More extensive profit for communities. 


\section{Registration}

Any Cooperative established in Kosovo is subject to registration within Kosovo Business Registration and shall come into existence only upon registration. The activities of a registered Cooperative shall be in compliance with the Law No.03/L004 on amending and supplementing of the Law on Farmers' Cooperatives No.2003/9, and the Statute of Cooperative ${ }^{1}$.

An Farmers' Cooperative shall have the rights and duties as a legal person independent of its members. It has its own appurtenant property and duties. It is responsible for its own property and for any act performed by it in its behalf.

The Law sets forth the establishment of the Federation of Farmers' Cooperative of Kosovo which is a professional body acting independently. The statute of the Federation shall be approved by the Assembly of the Federation with the prior consent of the Ministry, and shall be in compliance with the law and an administrative instruction issued by the Ministry. The funds of the Federation are generated by the Members and contribution of the Cooperatives and their Union.

\section{Conditions for Establishment}

All Farmer's Cooperatives shall be established by a minimum of five (5) farmers who shall all have written agreements with the cooperative? .

A Cooperative member enjoys the right to:

a) use the Cooperative's services with regard being had to the type of activities for which the Member has become a Member;

b) attend the general meeting of the assembly with voting rights regardless of the number of shares owned;

c) receive interest payments calculated on the Member's paid capital contribution at the rate stated by the Statutes;

d) receive the Cooperative's distributions in proportion with the activity realized with the Cooperative;

e) sell and transfer his shares according to the provisions of this law and the Cooperative's Statute;

f) receive the nominal value of the Member's shares after termination of the Member's membership, provided that the Accumulated Losses does not exceed the Reserve Funds and in accordance with other restrictions specified in this law and in the Cooperative's Statute.

\section{A Cooperative Member is obliged to:}

a) undertake specific agreed upon activities exclusively with the Framers Cooperative for at least three consecutive years in accordance with the Cooperative's statute with regard to the commitment made by the member;

b) contribute to the share capital the proportional value of his Activity Commitment and pay his shares in accordance with the legal and statutory requirements, or buy the number of shares required by his Activity Commitment;

c) bear liability for the Cooperative's debts up to an amount equal to the Member's Capital Contribution in case of insolvency ${ }^{3}$.

\section{Statute of cooperative member is gained:}

a) During cooperative funding, with the request endorsement for membership, endorsement of the statute or participation on the Founding Assembly where statute is approved.

\footnotetext{
1 Law No.2003 / 9 of Farmer Cooperatives, Article 2, Pristina on 15.05.2003

2 Law No.03 / L-004 on Amending and Supplementing the Law on Farmer's Cooperatives No.2003 / 9, Article 2, Pristina on 13.10.2008;

${ }^{3}$ Law No.2003 / 9 of Farmer Cooperatives, Article 7, Pristina on 15.05.2003
} 
b) Statute of cooperative member is gained after cooperative founding through the request for membership and the statement for cooperative statute admittance by what the signatory permits all the rights and obligations of the cooperative member.

A Decision to accept new members is taken by Steering Council within 30 days from submission of the request. The appeal against the decision on the membership request rejection can be submitted to the General Assembly. The Co-operative shall maintain a register of Co-operative Members indicating the number of shares owned by each Member as well as records of every transfer of shares.

\section{Cooperative member shall lose its statute by:}

Withdrawal of the member from cooperative; member exclusion; elimination or abandon the agriculture activity of the member who is a legal entity; death of the member and cooperative failure

a) Member of the co-operative may withdrawn from the co-operative with request for withdrawal which is pursued six months before the expiry of prescribed date. If the co-operative member has obligation towards the co-operative, statute of the member will end after obligation accomplishment.

b) Statute of co-operative member expires on the prescribed date on the decision for its exclusion from the co-operative due to the reasons defined by cooperative statute

c) Inheritors of the member may have member statute with the rights and obligations of the one who died, if for this decided the Steering Council and if they accomplish the conditions for having the statute of cooperative member.

d) Rights and obligations of the member, except property rights and obligations prescribed by special legal acts are dismissed on the day when terminates the statute of the member.

\section{Share Capital}

At the time of its establishment, the cooperative must declare the capital which is not limited. The capital of a Cooperative shall consist of the Contributions of cooperative Members and may be variable. Capital decrease is prohibited if the decrease would have the effect to cause the capital of the Cooperative to be less than half of the highest capital reached since the creation of cooperative. Capital contributions shall either be in cash or Contribution in Kind ${ }^{1}$. A contribution in activity is prohibited. Contribution in Kind during the establishment of the cooperative is assessed during the statute signing by founding members or founding assembly during the statute approval. Whereas, assessment of contribution in Kind during the cooperative work is performed by the general assembly. Members are severally and jointly liable towards third parties for having adopted any valuations of Contributions in Kind that are different from the value as assessed by the External Auditor. The right of a Member takes the form of shares only. The capital is divided into shares of equal value with each share having a minimum value of $10 €$.

\section{The General Assembly}

The general assembly which is the supreme body of the cooperative will be either ordinary or extraordinary. The powers of the ordinary general meeting of the assembly are limited to voting on matters not within the powers of the extraordinary meeting of the general assembly or other bodies of the cooperative.

\footnotetext{
1 Law No.2003 / 9 of Farmer Cooperatives, Article 9, Pristina on 15.05.2003
} 
The Steering Council referred to Article 12 convenes the general assembly meeting of the assembly at least once a year or when the bi-semester interim accounts shows losses. The general assembly may also be called by $25 \%$ of the cooperative members.

The minutes of the meetings of the assembly shall be recorded chronologically in a register to be maintained at the cooperative's registered office.

\section{External auditor}

The Ministry of Economy and Finance shall authorize qualified individuals to act as external auditors and shall designate an External Auditor to perform an annual audit for each cooperative, including:

a) verifying that the annual accounts truly and fairly represent the result of the cooperative's operations during the previous fiscal year, its financial situation and the cooperative's property;

b) verifying conformity of the accounting practices with the rules in force;

c) examining the accuracy and conformity of the annual accounts with the information given in the management report of the Steering Council

The Ministry of Finance and Economy shall bear the cost of the financial audit'.

\section{The Steering Council}

The Steering Council is the body of the cooperative which is vested with all the management powers except for those expressly within the authorities of other Cooperative bodies or powers limited by the cooperative's statutes and shall only be exercised within the limits of the cooperative's purpose.

The Steering Council shall have the following powers to:

a) review and revise the annual accounts of the cooperative and present them to the general assembly of the cooperative for approval;

b) elect and dismiss the president from amongst the Steering Council's members;

c) appoint a member of the cooperative to fill a vacancy of the Steering Council;

d) convene a general assembly of the cooperative and determine the general assembly's agenda;

e) appoint the cooperative's director;

f) admit or exclude members; and

g) borrow, issue securities or commercial paper, or secure debts of third parties.

The Steering Council shall consist of at least three but no more than nine members appointed by the statute or founding assembly when the cooperative is founded or by the general assembly in a regular meeting and shall serve for a period of at least three but no more than six (6) years².

\footnotetext{
1 Law No.2003 / 9 of Farmer Cooperatives, Article 11, Pristina on 15.05 .2003

2 Law No.2003 / 9 of Farmer Cooperatives, Article 12, Pristina on 15.05.2003
} 


\section{A member of the Steering Council:}

a) shall be a Member who is not liable for any debts towards the cooperative at the time of his appointment, and on whom no penalty for an economic crime has been imposed;

b) shall not be the spouse, the parents, children, of a member of the Steering Council;

c) shall not be an employee of the cooperative;

d) shall be at least 18 years old

A member of the Steering Council shall never borrow from the cooperative or obtain the guarantee of the cooperative for his own personal debt, and shall be personally liable for any breach of their duties toward either the cooperative or third parties.

A meeting of the Steering Council shall be convened by the president or by the president on demand by a $1 / 3$ of the members of the Steering Council. Minutes of the decisions of the Steering Council are chronologically recorded in registers maintained at the registered office of the cooperative.

\section{The President}

The president of the cooperative shall have the following powers to:

a) represent the cooperative in any suit;

b) execute all the decisions of the Steering Council excluding those decisions delegated to the Director; and

c) control the work of the director.

\section{The Director}

The director of the cooperative is in charge of the day-to-day management of the cooperative.. Also s/he has to adhere to certain conditions. The person holding the manager's position:

a) shall not be a cooperative Member;

b) shall have a labour contract;

c) shall not have been convicted for any economic based offence ;

d) cannot perform any simultaneous activity that would be in competition to the activity he performs for the cooperative

The functions of the director shall be described in the statute of the cooperative.

\section{Net Incomes and Losses}

Any annual net income shall be allocated in the following order of priority:

a) $5 \%$ in the compulsory reserve fund;

b) $5 \%$ to a Reserve Fund for reimbursement of shares for members who leave the Cooperative;

c) any amounts required by the statute of the cooperative for the reserve fund;

d) any amounts necessary to pay interest on the paid up capital of the cooperative Members;

e) any amounts to pay cooperative Members in proportion to their activities within the cooperative;

f) any remaining amounts to the account of accumulated surplus and losses, or other funds to be kept in reserve. 
Any Annual Loss shall be allocated to the account of accumulated surplus and losses. Members shall not receive any interest on shares and no allotment to the Reserve Funds is to be made if it hinders payment of any distributions or interests ${ }^{1}$.

When Net Assets due to losses are less than half of the highest share capital reached since the cooperative's foundation, an extraordinary meeting of the general assembly shall decide whether the cooperative should be liquidated or maintained. If the decision is to maintain the cooperative, the members shall contribute an amount necessary to bring the Net Assets of the cooperative to at least half of the highest share capital reached since the cooperative's foundation.

In the absence of such a decision by the general assembly, any aggrieved or interested party may bring the matter before a competent court, which may issue a decision requiring the liquidation of the cooperative.

Law No.2003 / 9 on Farmers Cooperatives also set forth the: Liquidation and Merger - Break-up of farmers' cooperatives

\section{Liquidation}

A cooperative is liquidated by virtue of:

a) the termination of the period for which it was established, or the completion of the activity for which it was formed unless a new activity is decided by the extraordinary meeting of the general assembly;

b) a vote of the extraordinary meeting of the general assembly, in accordance with the statutes of the cooperative decides by vote in unanimity of the cooperative Members;

c) a court order where the number of the co-operative members is less than the legal minimum; or there is a lack of decision of the general assembly as specified in Article

The cooperative being liquidated remains a legal entity during the liquidation period for the sole purpose of its liquidation. Liquidators are appointed by the general assembly unless the Court makes such an appointment ${ }^{2}$.

Net Assets remaining after payment of all creditors and the reimbursement of the contribution to the Members shall not be allocated to the Members. The Net Assets are compulsorily transferred to another Cooperative or to an Union of Framers Co-operative, or to another legal organisation of Framers Cooperatives. If a liquidation occurs pursuant to bankruptcy laws, the provisions set out in the Law No.2003/9 on farmers' cooperatives shall not apply.

\section{Merger - Break -up}

One or more Framers Cooperatives may transfer their interests to an existing Framers Cooperative or to a new Framers Cooperative established by those Cooperatives. A Cooperative may split itself into two or more Cooperatives by transferring its interests to new or existing Cooperatives. In both cases the Cooperative which transfers its interests pursuant to the Law No. 2003/9 ceases to exist without being liquidated. In case the co-operative stops existing due to the reasons on this article, co-operative assets will be transferred to its legal inheritors. Mergers and break-ups are only allowed between Cooperatives ${ }^{3}$.

The Law No.2003/9 on Farming Cooperatives set forth for the:

\section{Unions of the Framers Cooperatives (Unions)}

Unions of Framers Cooperatives (Unions) can be established through the adherence decision of two or more Framers Cooperatives which collaborate using their funds and their rights for the purpose of exercising a certain activity and must be registered in the office for registration of legal entities. The decision for adherence is taken by the Steering Council of

\footnotetext{
1 Law No.2003 / 9 of Farmer Cooperatives, Article 15, Pristina on 15.05.2003

2 Law No.2003 / 9 of Farmer Cooperatives, Article 17, Pristina on 15.05.2003

${ }^{3}$ Law No.2003 / 9 of Farmer Cooperatives, Article 18, Pristina on 15.05.2003
} 
each Cooperative and for this the general assembly during an ordinary meeting. If a Cooperative's contribution to a Union is limited to certain activities, the adherence decision shall specifically identify those activities. The members of the governing bodies of a Union of Cooperatives shall consist of representatives appointed by the Steering committees of each Cooperative. An Farmers Cooperative may neither be a member of a general partnership nor of any other form of business organization where member liability is not limited to their share contribution. An Framers Co-operative may own shares of a company engaged in business either by purchasing shares or by contributing to the share capital of such a company ${ }^{1}$.

The data on the number of Farmers' Cooperatives taken from the Kosovo Business Registration Agency for each Municipality are provided in the following table ${ }^{2}$.

\section{Farmers' Cooperatives according to the Municipalities}

\begin{tabular}{|c|c|c|}
\hline 1. & Deçan & 1 \\
\hline 2. & Gjakova & 6 \\
\hline 3. & Gllogoc & 5 \\
\hline 4. & Gjilan & 4 \\
\hline 5. & Dragash & 6 \\
\hline 6. & Istog & 5 \\
\hline 7. & Kaçanik & 0 \\
\hline 8. & Klina & 4 \\
\hline 9. & Fushe Kosova & 0 \\
\hline 10. & Kamenica & 1 \\
\hline 11. & Mitrovica & 1 \\
\hline 12. & Leposaviq & 2 \\
\hline 13. & Lipjan & 2 \\
\hline 14. & Novo Brdo & 0 \\
\hline 15. & Obiliq & 1 \\
\hline 16. & Rahovec & 5 \\
\hline 17. & Peja & 2 \\
\hline 18. & Podujeva & 2 \\
\hline 19. & Prishtinë & 7 \\
\hline 20. & Prizren & 7 \\
\hline 21. & Skenderaj & 5 \\
\hline 22. & Shtime & 5 \\
\hline 23. & Shterpce & 1 \\
\hline 24. & Suhareka & 1 \\
\hline 25. & Ferizaj & 2 \\
\hline 26. & Viti & 2 \\
\hline 27. & Vushtrri & 2 \\
\hline 28. & Zubin Potok & 0 \\
\hline 29. & Zveqan & 0 \\
\hline 30. & Malisheva & 3 \\
\hline 31. & Graçanica & 1 \\
\hline 32. & North Mitrovica & 0 \\
\hline 33. & Hani i Elezit & 0 \\
\hline \multicolumn{2}{|c|}{ Total: } & 83 \\
\hline
\end{tabular}

\section{Conclusions}

The establishment of cooperative can be a great challenge but also a very significant event. It requires very high confidence in the functioning of the cooperative model, a lot of knowledge, research, planning, patience and dedication. The development of cooperative maybe will not come early as it has been planned by the founders but we must have patience 
for more time from what is foreseen by the founding act. Groups, members, founders of the cooperative who devote themselves own financial means and time, with their dedication and commitment in the end will be evaluated with positive results and financial benefits. Founders of the cooperative makes union labor and capital for many financial benefits for themselves and for business - Cooperative.

\section{Bibliography}

[1] Law No.2003 / 9 of Farmer Cooperatives, Pristina on 15.05.2003;

[2] Law No.03 / L-004 on Amending and Supplementing the Law on Farmer's Cooperatives No.2003 / 9, Pristina on 13.10.2008;

[3] Law No.02 / L-123 on Business, Pristina 29/03/2007;

[4] Law No.04 / L-006 for Amamandamentimin and Supplementing the Law No. 02 / L-123;

[5] UNMIK's Regulation, No.2001 / 6 on Business;

[6] UNMIK Regulation, No.2000 / 8 on Temporary Registration of Businesses;

[7] Kosovo Business Registration Agency;

[8] www.arbk.org.

[9] Law Nr.38 / 2012 Agricultural Cooperative Societies, Tirana 23.04.2012. 